\title{
ISTRI MENGGUGAT CERAI SUAMI AKIBAT BERPOLIGAMI ATAU SEBAB LAIN (ANALISIS HUKUM ISLAM DAN UNDANG-UNDANG)
}

\author{
Muh. Yunan Putra \\ Institut Agama Islam (IAI) Muhammadiyah Bima \\ Jln. Anggrek Nomor 16 Ranggo Nae Kota Bima \\ mohammed.elgehady@gmail.com
}

\section{Abstrak}

Di Indonesia, maraknya pernikahan dibawah umur menjadi hal dan penyebab utama terjadinya peningkatan angka perceraian. Kurang stabilnya dalam menghadapi persoalan rumah tangga menjadi alasan pertengkaran dalam penikahan tersebut. Suami dengan mudahnya mengucapkan dan melemparkan kata-kata dan kalimat cerai terhadap istri, demikan istri dengan mudahnya mendatangi Pengadilan Agama atau Pengadilan Negeri untuk menggugat suami karena tidak tahan dengan perlakuan dan tindakan suami. Pada hakikatnya Islam tidak melarang atau bahkan membolehkan seorang istri menggugat seorang suami layaknya seorang suami menalak sang istri, demikian juga dalam hukum Undangundang atau peraturan pemerintah, tidak melarang sama sekali selama dengan maksud dan tujuan serta alasan yang kuat. Namun perlu kiranya dipahami bahwa segala perbuatan dan tindakan tidak semudah yang dipikirkan, terlebih penikahan yang dianggap sesuatu yang sakral oleh Agama Islam. Putusnya ikatan pernikahan berarti putus juga ikatan silaturrahim yang telah dijalin selama pernikahan, dan inilah salah satu sebab kenapa Allah sangat membenci perbuatan yang halal tersebut 
(perceraian).

Keywords: Menggugat Cerai; Poligami; Hukum Islam; Undangundang.

\section{Pendahuluan}

Poligami di Indonesia khususnya, merupakan topik pembahasan yang menarik dan tidak pernah habis-habisnya untuk dibahas terutama dilakangan kaum Adam. Topik ini kerap kali terdengar dibicarakan dan dibahas oleh bapakbapak mulai dari kantor, instansi, sekolah bahkan sampai di kedai kopi. Demikian pula dibahas dan dikaji di seminarseminat umum maupun khusus hingga dibuatkan metode dan cara oleh para pakar yang telah lama mempraktekkannya dengan harapan memberikan contoh dan motovasi kepada siapa saja yang berniat untuk mengikuti jejak langkah tersebut.

Sebaliknya dikalangan kaum Hawa, poligami adalah pembahasan yang paling menyakitkan dan sangat dibenci sehingga hampir tidak pernah didengar dibicarakan oleh kaum wanita, tidak jarang beberapa diantaranya mengutuk perbuatan tersebut bahkan dengan minimnya ilmu dan pengetahuan mempertanyakan kebenaran ayat dan hadits tentang poligami; kalau itu ayat, apakah benar dari Allah swt. dan kalau itu hadits, apakah benar Rasulullah mensyariatkan juga praktek poligami kepada umatnya?

Dibenci dan dikutuknya perbuatan poligami oleh sebagian kaum Hawa bukan tampa sebab, kepala keluarga (suami) yang memiliki istri lebih dari satu rata-rata memiliki masalah dalam rumah tangga, anak-anak menjadi korban karena kurangnya perhatian dari seorang ayah, perhatian terhadap istri tua-pun menjadi kurang karena terlalu fokus kepada istri baru dan masih banyak lagi. Oleh banyaknya 
permasalahan yang muncul, maka tidak heran kebanyakan para istri yang suaminya berpoligami mengambil tindakan untuk menuntut cerai demi menghindari permasalahan yang menyakitkan tersbebut.

Lalu bagaimana sebenarnya hukum poligami menurut Islam dan Undang-undang, bolehkah seorang istri menggugat cerai seorang suami karena berpoligami, apakah sajakah hakhak istri terhadap suami setelah melakukan poligami? Inilah yang hendak penulis bahas dengan harapan memberikan manfaat kepada penulis pribadi dan para pembaca.

\section{Pengertian}

Sebelum terlalu jauh membahas tentang poligami dan beberapa pembahasan didalamnya, penulis merasa perlu kiranya menjelaskan beberapa pengertian tentang beberapa point penting yang menjadi pokok pembahasan.

\section{Menggugat Cerai}

Menggugat cerai terdiri dari dua suku kata, yaitu menggugat dan cerai. Menggugat sendiri sebagaimana ditemukan dalam Kamus Besar Bahasa Indoneia (KBBI) artinya mendakwa atau mengadukan perkara. Sedangkan cerai adalah terpisahnya hubungan sebagai suami dan istri atau yang biasa juga disebut talak.

Maka menggugat cerai atau yang dalam istilah lain biasa disebut cerai gugat adalah ikatan perkawinan yang putus sebagai akibat permohonan yang diajukan oleh istri ke Pengadilan Agama, yang kemudian termohon (suami) menyetujuinya, sehingga pengadilan agama mengabulkan permohonan dimaksud. ${ }^{1}$

1 Zainuddin Ali. 2009. Hukum Perdata Islam di Indonesia. Jakarta: Sinar Grafika. Hal. 81.

Sangaji Jurnal Pemikiran Syariah dan Hukum 
Ahrum Hoerudin juga menambahkan pengertian Cerai Gugat secara luas ialah suatu gugatan yang diajukan oleh penggugat (pihak isteri) kepada Pengadilan Agama, agar tali perkawinan dirinya dengan suaminya diputuskan melalui suatu putusan Pengadilan Agama, sesuai dengan aturan hukum yang berlaku. ${ }^{2}$

2. Poligami

Dalam kamus hukum, Poligami adalah ikatan di mana salah satu pihak mempunyai atau menikah beberapa lawan jenis dalam waktu yang tidak berbeda. ${ }^{3}$

Secara etimologi kata-kata poligami berasal dari bahasa yunani yaitu polus yang artinya banyak dan gamein yang artinya kawin. ${ }^{4}$ Maka jika kedua kata ini digabungkan akan berarti suatu perkawinan yang banyak. Sedangkan secara terminologi, poligami yaitu seorang laki-laki mempunyai lebih dari satu istri atau seorang lakilaki beristri lebih dari seorang, tetapi dibatasi paling banyak empat orang. ${ }^{5}$

Sedangkan menurut Abdullah, poligami adalah lakilaki yang beristri lebih dari satu orang wanita dalam satu

2 Ahrum Hoerudin. 1999. Pengadilan Agama (Bahasan Tentang Pengertian, Pengajuan Perkara, dan Kewenangan Pengadilan Agama Setelah Berlakunya UndangUndang Nomor 7 Tahun 1989 Tentang Peradilan Agama). Bandung: PT. Aditya Bakti. Hal. 20.

3 Rijal Imanullah. 2016. Poligami dalam Hukum Islam Indonesia (Analisis Terhadap Putusan Pengadilan Agama NO. 915/ Pdt.G/ 2014/PA.BPP Tentang Izin Poligami). Mazahib; Jurnal Pemikiran Hukum Islam. Vol. XV, No. 1 Juni 2006. Hal. 108. Lihat juga: Sudarsono. 2009. Kamus Hukum, Cet. VI. Jakarta: Rineka Cipta. Hal. 364.

${ }^{4}$ Hakim Rahmat. Tth. Hukum Perkawinan Islam. Bandung: Pustaka Setia. Hal. 13.

5 Ibid. lihat juga: Abd. Rahman Ghazaly. 2006. Figh Munakahat, Cet. II. Jakarta: Kencana. Hal. 129. 
ikatan perkawinan. Seperti seorang suami mungkin mempunyai dua istri atau lebih pada saat yang sama. ${ }^{6}$

\section{Hukum Islam}

Muhammad Daud Ali menyebutkan bahwa kata hukum yang berasal dari lafadz Arab tersebut bermakna norma, kaidah, ukuran, tolok ukur, pedoman, yang digunakan untuk menilai dan melihat tingkah laku manusia dengan lingkungan sekitarnya. Sedangkan Islam adalah bentuk mashdar dari akar kata aslama-yuslimuislaman yang mengandung arti ketundukan dan kepatuhan serta bisa juga bermakna Islam, damai, dan selamat. Namun kalimat asal dari lafadz islam adalah berasal dari kata salima-yaslamu-salaman-wa salamatan yang memiliki arti selamat (dari bahaya), dan bebas (dari cacat). ${ }^{7}$

Maka menurut Muchammad Ichsan hukum Islam adalah hukum yang berasal dari agama Islam yang diturunkan oleh Allah untuk kemaslahatan hambahambaNya di dunia dan akhirat. ${ }^{8}$

\section{Undang-undang}

Undang-Undang adalah Peraturan Perundangundangan yang dibentuk oleh Dewan Perwakilan Rakyat (DPR) dengan persetujuan bersama Presiden. Sedangkan Peraturan Perundang-undangan adalah peraturan tertulis

${ }^{6}$ Reza Fitra Ardhian dkk. 2015. Poligami dalam Hukum Islam dan Hukum Positif Indonesia Serta Urgensi Pemberian Izin Poligam di Pengadilan Agama. Jurnal Privat Law, Vol. III, No. 2 Juli-Desember 2015. Hal. 100.

7 Rohidin. 2016. Pengantar Hukum Islam, Dari Semenanjung Arabia hingga Indonesia, Cet, I. Yogyakarta; Lintang Rasi Aksara Books. Hal. 2.

${ }^{8}$ Muchammad Ichsan. 2015. Pengantar Hukum Islam, Cet. I. Yogyakarta; Gramasurya. Hal. 2.

Sangaji Jurnal Pemikiran Syariah dan Hukum 
yang memuat norma hukum yang mengikat secara umum dan dibentuk atau ditetapkan oleh lembaga negara atau pejabat yang berwenang melalui prosedur yang ditetapkan dalam Peraturan Perundang-undangan. ${ }^{9}$

\section{Pembahasan}

Seorang istri menggugat cerai suami sebenarnya telah terjadi sejak jaman Rasulullah saw. masih hidup, hal ini sebagaimana dijelaskan dalam hadits berikut;

Dari Ibnu 'Abbas Radhiyallahu anhuma ia berkata, Isteri Tsabit bin Qais bin Syammas menghadap Rasulullah Shallallahu 'alaihi wa sallam dan berkata:

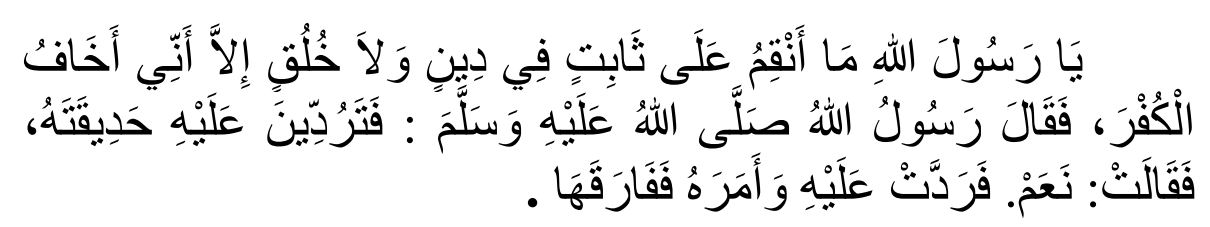

Artinya:

"Wahai Rasulullah, aku tidak mencela Tsabit dalam hal agama dan akhlaknya, akan tetapi aku takut akan kufur." Maka Rasulullah Shallallahu 'alaihi wa sallam bersabda, "Apakah engkau mau mengembalikan kebun kepadanya?" Ia menjawab, "Ya." Maka kemudian kebun itu dikembalikan kepada Tsabit bin Qais dan menyuruhnya untuk menceraikan isterinya." (HR. Al Bukhari, No. 5276)

Dari hadits yang disebutkan diatas, diambil beberapa kendungan diantaranya;

9 Lihat: Undang-Undang Republik Indonesia Nomor 12 Tahun 2011 Tentang Pembentukan Peraturan Perundang-Undangan, BAB I Ketentuan Umum Pasal 1, Point 2 dan 3. Hal. 2. 
1. Seorang istri yang menggugat cerai suami telah terjadi sejak jaman Nabi saw.

2. Pada waktu-waktu tertentu dengan melihat keadaan dibolehkan bagi seorang istri untuk menggugat ceai seorang suami.

3. Seorang istri yang menggugat cerai suami diwajibkan untuk mengembalikan mahar yang pernah diberikan oleh suami kepadanya.

Di Indonesia sendiri, seorang istri menggugat cerai suami sudah menjadi suatu pemandangan yang biasa bahkan sudah dianggap sesuatu yang biasa, entah karena permasalahan besar yang dihadapi dalam rumah tangga sampai kepada persoalan sepele yang sebagian orang malu untuk diceritakan apalagi sampai menyebabkan perceraian.

Hal ini (perceraian) terjadi karena beberapa hal, diantaranya pernikahan dini atau dibawah usia matang berumah tangga sehingga belum siap ketika dihadapkan dengan permasalahan yang kerap kali terjadi. Lainnya orang tua ikut campur dalam permasalahan rumah tangga anak sehingga selalunya menyudutkan menantu sehingga terjadilah sesuatu yang tidak diinginkan tersebut. Lalu sebagian lain, seorang suami berpoligami dibelakang istri (tampa sepengetahuan istri pertama), sehingga ketika mengetahui suami telah menikah lagi dengan wanita lain, maka ia-pun menggugat suaminya ke pengadilan.

\section{Pandangan Hukum Islam}

Telah disebutkan sebelumnya bahwa hukum Islam adalah hukum yang berasal dari agama Islam yang diturunkan oleh Allah untuk kemaslahatan hambahambaNya di dunia dan akhirat. Artinya hadirnya Islam 
ditengah kehidupan masyarakat, khususnya kaum Muslimin adalah rahmat yang memberikan setitik cahaya terang terhadap gelapnya dunia, juga sebagai berkah yang membawa kebaikan terhadap kerusakan yang tengah terjadi, dan sebagai petunjuk yang mengarahkan kepada jalan yang lurus terhadap banyaknya kesesatan yang meraja lela. Inilah arti ungkapan Allah swt dalam firman-Nya;

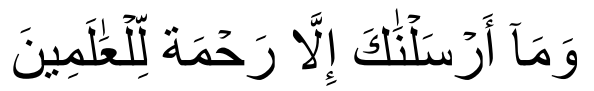

Terjemahnya:

"Dan tiadalah Kami mengutus kamu, melainkan untuk (menjadi) rahmat bagi semesta alam." (QS. Al Anbiya; 107) $)^{10}$

Hadirnya Rasulullah saw. yang membawa agama Islam dan risalah-risalah kebaikan adalah merupakan sebuah rahmat yang tidak hanya dirasakan oleh segenap umatnya, melainkan oleh seluruh alam; binatang, tumbuh-tumbuhan, bahkan orang kafir sekalipun mendapat percikan kebaikan dari kehadirannya.

Demikian dalam permasalahan rumah tangga, tiada rumah tangga yang lebih menjadi contoh yang wajib diteladani kecuali rumah tangga Rasulullah saw., bagaimana istri-istrinya kepada beliau dan bagaimana beliau memperlakukan para umahatul mu'minin.

Permasalahan rumah tangga tergolong permasalahan yang pelik, terkadang orang lain tidak dapat memahaminya dan hanya suami dan istri yang merasakan atau tahu persis apa yang sedang mereka hadapi. Seperti contoh; seorang suami menikah lagi lalu sang istri protes, padahal sang suami adalah orang yang sangat kaya dan dermawan. Orang

${ }^{10}$ Khadīm al Haramain al Syarifain. T.th. Al-Qur'an dan Terjemahan Maknanya. Komplek Percetakan Al Qur'an Al Karim Raja Fahd. Hal. 508.

Volume 5, Nomor 2, Oktober 2021 
hanya akan melihat dan berpendapat bahwa istrinya terlalu egois atau ingin menguasai harta suami, namun mereka tidak pernah tahu bahwa protesnya seorang istri bukan karena ingin menguasai harta namun karena melihat keadaan suami yang sudah tidak memungkinkan untuk memiliki istri baru, mungkin karena sudah terlalu tua dan lemah, atau impoten, atau tempramen yang menimbulkan KDRT (istri hanya diam tampa melapor karena cintanya kepada suami), atau hal-hal lain yang mengharamkan lakilaki tersebut untuk melakukan poligami.

Lalu bagaimana menurut pandangan hukum Islam ketika seorang istri menggugat seorang suami karena berpoligami? Dalam Islam istri yang menggugat cerai suami biasa disebut dengan khulu' yang artinya menanggalkan atau membuka pakaian, atau secara istilahnya menebus istri akan dirinya kepada suaminya dengan hartanya, maka tertalaklah dirinya. Dan maksud khulu' yang dikehendaki menurut ahli fikih adalah permintaan isteri kepada suaminya untuk menceraikan dirinya dari ikatan perkawinan dengan disertai pembayaran 'iwadh, berupa uang atau barang kepada suami dari pihak isteri sebagai imbalan penjatuhan talaknya.

Abu Zahrah mendefinisikan bahwa khulu' mempunyai dua arti, yaitu am (umum) dan khas (khusus). Khulu' dalam arti umum adalah talak atas harta istri untuk menebus dirinya yang diserahkan kepada suaminya baik dengan lafazh khulu' atau lafazh mubaro'ah atau dengan lafazh talak. Pengertian ini banyak digunakan oleh ulama kontemporer. Adapun khulu' dalam arti khas adalah talak tebus dengan lafazh khulu', pendapat ini banyak digunakan oleh ulama salaf. ${ }^{11}$

11 Darmiko Suhendra. 2016. Khulu' dalam Persfektif Hukum Islam. Jurnal AsySyar'iyyah Vol. 1 No. 1 2016. Hal. 221-222. Lihat juga: Muhammad Abu Zahrah. 2005. Ahwal Syahkshiyyah. Kairo: Daar el Fikri. Hal. 329.

Sangaji Jurnal Pemikiran Syariah dan Hukum 
Dengan melihat hadits yang disebutkan sebelumnya, serta ditambah dengan firman Allah swt. dalam Surat al Baqarah 229;

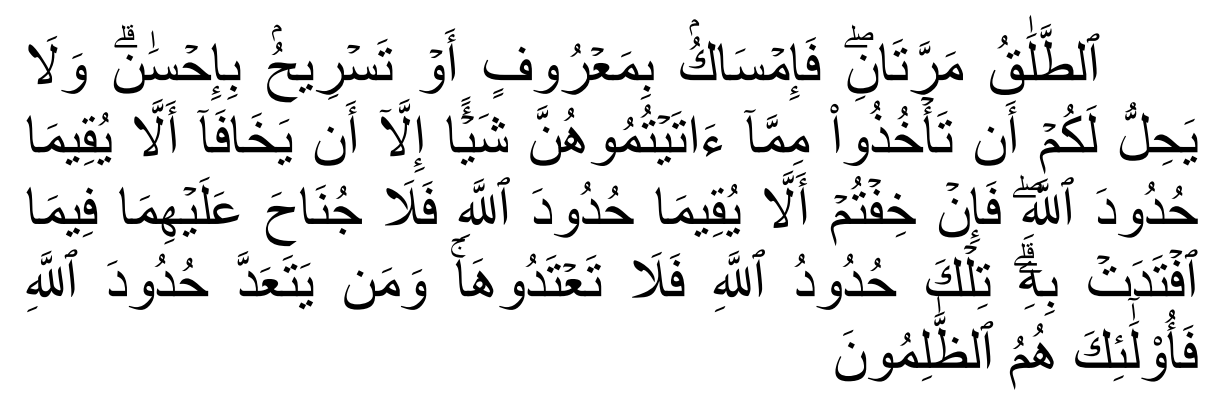

Terjemahnya:

"Talak (yang dapat dirujuki) dua kali. Setelah itu boleh rujuk lagi dengan cara yang ma'ruf atau menceraikan dengan cara yang baik. Tidak halal bagi kamu mengambil kembali sesuatu dari yang telah kamu berikan kepada mereka, kecuali kalau keduanya khawatir tidak akan dapat menjalankan hukum-hukum Allah. Jika kamu khawatir bahwa keduanya (suami isteri) tidak dapat menjalankan hukum-hukum Allah, maka tidak ada dosa atas keduanya tentang bayaran yang diberikan oleh isteri untuk menebus dirinya. Itulah hukum-hukum Allah, maka janganlah kamu melanggarnya. Barangsiapa yang melanggar hukum-hukum Allah mereka itulah orang-orang yang zalim." (QS. Al Baqarah: 229) $)^{12}$

Maka para jumhur ulama mengambil kesimpulan bahwa hukum asal/asli dari khulu' adalah mubah (boleh-boleh saja). Pemberian hak kepada istri untuk menggugat cerai seorang suami sepertinya semakin memberikan bukti bahwa Islam adalah agama yang membawa rahmat serta adil dalam pengambilan hukum. Sehingga seorang istripun boleh

${ }^{12}$ Khadīm al Haramain al Syarifain. T.th. Al-Qur'an dan Terjemahan Maknanya. Komplek Percetakan Al Qur'an Al Karim Raja Fahd. Hal. 55. 
mengajukan perceraian terhadap suami ketika keadaan memungkinkan dan mendesak.

Demikian dalam pengembalian harta suami oleh istri akibat khulu', hendaknya seorang suami tidak menyusahkan istri dalam pengembalian harta yang sebelumnya diserahkan kepada istri; baik dalam bentuk mahar atau yang lainnya, hal ini sebagaimana dalam firman-Nya;

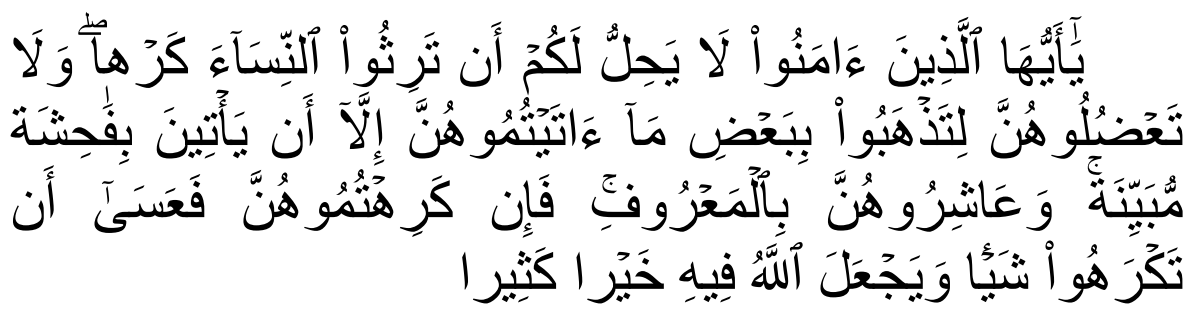

Terjemahnya:

"Hai orang-orang yang beriman, tidak halal bagi kamu mempusakai wanita dengan jalan paksa dan janganlah kamu menyusahkan mereka karena hendak mengambil kembali sebagian dari apa yang telah kamu berikan kepadanya, terkecuali bila mereka melakukan pekerjaan keji yang nyata. Dan bergaullah dengan mereka secara patut. Kemudian bila kamu tidak menyukai mereka, (maka bersabarlah) karena mungkin kamu tidak menyukai sesuatu, padahal Allah menjadikan padanya kebaikan yang banyak." (QS. Al Nisa'; 19) ${ }^{13}$

Kendatipun khulu' adalah sesuatu yang dibolehkan oleh hukum Islam, namun ada beberapa hal kiranya sangat perlu untuk digaris bawahi dalam hal ini, diantaranya;

1. Kebolehan melakukan khulu' hendaknya berdasarkan kepada sesuatu yang sangat kuat, artinya seorang istri

${ }^{13}$ Khadīm al Haramain al Syarifain. T.th. Al-Qur'an dan Terjemahan Maknanya. Komplek Percetakan Al Qur'an Al Karim Raja Fahd. Hal. 119.

Sangaji Jurnal Pemikiran Syariah dan Hukum 
hendaknya memiliki tujuan dan alasan yang tidak terbantahkan.

Sejumlah besar ulama salaf dan khalaf mengatakan bahwa tidak boleh khulu' kecuali terjadi perselisihan dan nusyuz dari pihak istri. Sedangkan Imam Syafi'i berpandangan bahwa khulu' itu boleh dalam kondisi perselisihan dan keharmonisan. Namun khulu' dalam kondisi pertama adalah lebih utama dan sesuai dengan yang ia pilih. ${ }^{14}$

Slamet Abidin ${ }^{15}$ dalam bukunya Fikih Munakahat menjelaskan bahwa alasan istri diperbolehkannya seorang istri melakukan khulu' diantaranya;

a) Suami murtad

b) Suami berbuat kekufuran atau kemusyrikan kepada Allah dengan berbagai macam dan bentuknya dan telah disampaikan nasehat kepadanya agar bertaubat darinya tapi tidak mendengar dan menerima.

c) Suami melarang dan menghalangi isteri untuk melaksanakan kewajibankewajiban agama, seperti kewajiban shalat lima waktu, kewajiban zakat, memakai hijab syar'i, menuntut ilmu syar'i yang hukumnya fardhu 'ain.

d) Suami berakidah dan bermanhaj sesat dan menyesatkan dari agama Allah yang lurus dan haq.

14 Darmiko Suhendra. 2016. Khulu' dalam Persfektif Hukum Islam. Jurnal AsySyar'iyyah Vol. 1 No. 1 2016. Hal. 221-222. Lihat juga: Hamka. 2015. Tafsir AlAzhar, Juz I. Jakarta; Gema Insani. Hal. 440.

${ }^{15}$ Slamet Abidin. 1999. Fiqih Munakahat, Cet. II. Bandung: CV. Pustaka Setia. 
e) Suami bersikap kasar, keras dan berakhlak buruk.

f) Suami tidak mampu memberi nafkah wajib bagi isteri.

g) Isteri merasa benci dan sudah tidak nyaman hidup bersama suaminya, bukan karena agama dan akhlaknya, tapi karena khawatir tidak bisa memenuhi haknya.

2. Terjadinya perceraian akibat khulu' sama dengan perceraian akibat talak, artinya terjadinya perceraian tersebut menyebabkan terputusnya silaturrahim. Sedangkan dalam beberapa hadits Allah swt. sangat membenci perbuatan tersebut bahkan Rasulullah mengatakan bahwa orang yang memutuskan silaturrahim di neraka tempatnya;

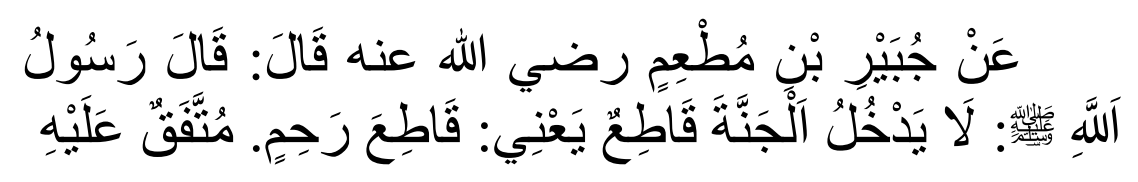

Artinya:

Dari Jubair bin Muth'im radhiyallahu 'anhu, ia berkata bahwa Rasulullah shallallahu 'alaihi wa sallam bersabda, "Tidak akan masuk surga orang yang memutus silaturahim." (HR. Bukhari, No. 2984 dan Muslim, No. 2556)

3. Tindakan melakukan khulu' hendaknya memiliki tujuan yang baik dan lurus; seperti menghindari bahaya akibat pertengkaran yang hebat atau agar lebih menjadikan diri tenang dalam beribadah kepada Allah swt. tampa harus terus menerus memikirkan permasalahan. Hal ini

Sangaji Jurnal Pemikiran Syariah dan Hukum 
sebagaimana yang diucapkan oleh Al Zurjawi bahwa khulu' sendiri sebenarnya dibenci oleh syariat yang mulia seperti halnya talak. Semua akal dan perasaan sehat menolak khulu', hanya Allah swt. saja Yang Maha Bijaksana memperbolehkannya untuk menolak bahaya ketika tidak mampu menegakan hukum-hukum Allah swt. Maksudnya Hikmah khulu' untuk menghindari bahaya, yakni saat terjadinya pertengkaran hebat yang menimbulkan gejolak dalam hubungan suami isteri hingga keduanya tidak bisa disatukan lagi dalam ikatan rumah tangga, maka khulu' diperbolehkan. Hal ini agar keduanya tetap berjalan dalam kehidupan masingmasing dan menjalankan kewajibannya sebagai hamba Allah. ${ }^{16}$

\section{Pandangan Undang-undang}

Menurut Undang-undang Republik Indonesia Nomor 1 Tahun 1974, Perkawinan adalah ikatan lahir batin antara seorang pria dan seorang wanita sebagai suami istri dengan tujuan membentuk keluarga atau rumah tangga yang bahagia dan kekal berdasarkan Ketuhanan Yang Maha Esa. ${ }^{17}$

Jika demikian, maka perkawinan merupakan suatu sarana untuk menciptakan rumah tangga yang bahagia, sejahtera, rumah tangga yang sakinah, mawadah dan rahmah yang penuh dengan kasih sayang, tentram,

${ }^{16}$ Darmiko Suhendra. 2016. Khulu' dalam Persfektif Hukum Islam. Jurnal AsySyar'iyyah Vol. 1 No. 1 2016. Hal. 221-222. Lihat juga: Ali Ahmad Al-Jurzawi. 1992. Hikmah Al-Tasyri Wa Falsafatuh (Falsafah dan Hikmah Hukum Islam), Alih bahasa Hadi Mulyo dan Sabahus Surur. Semarang: CV As-Syifa. Hal. 320.

17 Lihat: Undang-undang Republik Indonesia Nomor 1 Tahun 1974 Tentang Perkawinan, BAB I Dasar Perkawinan Pasal 1. Hal. 2. 
pengertian dan saling toleransi untuk selama-lamanya. Karena setiap pasangan suami isteri dalam suatu keluarga mengharapkan dapat saling mengerti hak dan kewajiban satu sama lain serta berusaha untuk melaksanakannya. Karena hal itu merupakan landasan utama untuk mendapatkan kebahagian yang sempurna dalam menjaga keutuhan keluarga.

Sedangkan khulu' menurut undang-undang dalam Kompilasi Hukum Islam adalah perceraian yang terjadi atas permintaan istri dengan memberikan tebusan atau iwadl kepada dan atas persetujuan suaminya. Dengan demikian, maka khulu' adalah salah satu penyebab terjadinya percaraian dalam kehidupan berumah tangga. Hal ini sebagaimana tertera pada pasal $19^{18}$ yang menyatakan bahwa;

Perceraian dapat terjadi karena alasan atau alasanalasan:

1. Salah satu pihak berbuat zina atau menjadi pemabuk, pemadat, penjudi dan lain sebagainya yang sukar disembuhkan;

2. Salah satu pihak meninggalkan pihak lain selama 2 (dua) tahun berturut-turut tanpa izin pihak lain dan tanpa alasan yang sah atau karena hal lain diluar kemampuannya;

3. Salah satu pihak mendapat hukuman penjara 5 (lima) tahun atau hukuman yang lebih berat setelah perkawinan berlangsung;

18 Lihat: Peraturan Pemerintah Republik Indonesia Nomor 9 Tahun 1975

Tentang Pelaksanaan Undang-Undang Nomor 1 Tahun 1974 Tentang Perkawinan.

Sangaji Jurnal Pemikiran Syariah dan Hukum 
4. Salah satu pihak melakukan kekejaman atau penganiayaan berat yang membahayakan pihak lain;

5. Salah satu pihak mendapat cacat badan atau penyakit dengan akibat tidak dapat menjalankan kewajibannya sebagai suami atau isteri;

6. Antara suami dan isteri terus menerus terjadi perselisihan dan pertengkaran dan tidak ada harapan akan hidup rukun lagi dalam rumah tangga;

7. Suami melanggar taklik talak;

8. Peralihan agama atau murtad yang menyebabkan terjadinya ketidak rukunan dalam rumah tangga.

Sudono ${ }^{19}$ mengungkapkan bahwa Kompilasi Hukum Islam (KHI) membedakan cerai gugat dengan khulu'. Namun demikian, ia mempunyai kesamaan dan perbedaan di antara keduanya. Persamaannya adalah: keinginan untuk bercerai datangnya dari pihak isteri. Perbedaannya, yaitu cerai gugat tidak selamanya membayar 'iwadl (uang tebusan) yang menjadi dasar terjadinya khulu' atau perceraian. Khulu' yang dimaksud, diatur dalam pasal $148 \mathrm{KHI}$ dengan prosedur sebagai berikut:

1. Seorang isteri yang mengajukan gugatan perceraian dengan jalan khulu', menyampaikan permohonannya kepada Pengadilan Agama yang mewilayahi tempat tinggalnya disertai alasan atau alasan-alasannya.

19 Sudono. 2019. Penyelesaian Perceraian dengan Khulu dan Akibat Hukumnya. diakses pada 15 Maret 2019. https://www.pa-blitar.go.id/informasipengadilan/164-penyelesaian-perceraian-dengan-khulu-dan-akibathukumnya.html. 
2. Pengadilan Agama selambat-lambatnya satu bulan memanggil isteri dan suaminya untuk di dengar keterangannya masing-masing.

3. Dalam persidangan tersebut Pengadilan Agama memberikan penjelasan tentang akibat khulu', dan memberikan nasehat-nasehatnya.

4. Setelah kedua belah pihak sepakat tentang besarnya 'iwadl atau tebusan, maka Pengadilan Agama memberikan penetapan tentang izin bagi suami untuk mengikrarkan talaknya di depan sidang Pengadilan Agama. Terhadap penetapan itu tidak dapat dilakukan upaya banding dan kasasi.

5. Penyelesaian selanjutnya ditempuh sebagaimana yang di atur dalam pasal 131 ayat $5^{20}$.

6. Dalam hal tidak tercapai kesepakatan tentang besarnya tebusan atau 'iwadl, Pengadilan Agama memeriksa dan memutuskan sebagai perkara biasa.

Dari uraian di atas, Sudono ${ }^{21}$ menambahkan bahwa nampak perbedaan antara cerai gugat dan khulu'. Namun, Undang-Undang No. 7 Tahun 1989 dan Peraturan

${ }^{20}$ Pasal 131 ayat 5: Setelah sidang penyaksian ikrar talak Pengadilan Agama membuat penetapan tentang terjadinya Talak rangkap empat yang merupakan bukti perceraian baki bekas suami dan istri. Helai pertama beserta surat ikrar talak dikirimkan kepada Pegawai Pencatat Nikah yang mewilayahi tempat tinggal suami untuk diadakan pencatatan, helai kedua dan ketiga masingmasing diberikan kepada suami istri dan helai keempat disimpan oleh Pengadilan Agama.

21 Sudono. 2019. Penyelesaian Perceraian dengan Khulu dan Akibat Hukumnya. diakses pada 15 Maret 2019. https://www.pa-blitar.go.id/informasipengadilan/164-penyelesaian-perceraian-dengan-khulu-dan-akibathukumnya.html. 
Pemerintah No. 9 tahun 1975 tidak membedakan antara keduanya sehingga tidak membicarakannya. Karenanya penyelesaian berdasarkan pasal $148 \mathrm{KHI}$ yang semula perkara cerai gugat dengan khulu' setelah ada putusan Pengadilan Agama lalu eksekusinya mengacu pada pasal 131 ayat 5 yaitu suami mengikrarkan talaknya terhadap istri.

Proses penyelesaian yang berakhir dengan ikrar suami, dalam hal ini bagi perkara yang tidak ada kesulitan, seperti tidak ada rekonpensi dari suami atau tidak ada gugatan cerai yang dikumulasi dengan gugatan bersama ${ }^{22}$ tentu penyelesaiannya lebih sulit, sehingga Mahkamah Agung telah mengantisipasi bahwa untuk mengesampingkan ketentuan pasal $148 \mathrm{KHI}$, lagi pula menurut Sudono mungkin selama ini belum ada Pengadilan Agama yang mengabulkan permohonan eksekusi harta bersama atas putusan cerai talak (versi pasal $148 \mathrm{KHI}$ dengan mengacu pasal 131 ayat $5 \mathrm{KHI}$ ) yang direkonpensi dengan harta bersama, dimana putusan tersebut telah berkekuatan hukum tetap akan tetapi Pengadilan Agama tidak berani mengabulkan permohonan eksekusi harta bersamanya dengan alasan pemohon dan termohon secara yuridis masih terikat dalam perkawinan (belum bercerai), padahal antara suami istri sudah jelas tidak mungkin lagi untuk rukun kembali $^{23}$. Kelemahan tetap di pihak istri kalau ada salah satu pihak yang mengkumulasikan gugatan/permohonan dengan harta bersama atau suami yang mengajukan gugatan rekonpensi harta bersama tentu banyak kendala, waktu yang berlarut-larut kapan selesainya.

${ }^{22}$ Lihat: Pasal 86 ayat (1) UU No. 7 Tahun 1989 tentang Peradian Agama.

${ }^{23}$ Lihat: Sudono. 2014. Senarai Pembaharuan Hukum Peradilan Agama Kajian Hukum Formil dan Materiil; Edisi Revisi. Surabaya PTA. Hal. 134. 


\section{Analisi Hukum dan Simpulan}

Dari dua penjelasan hukum tersebut sebelumnya; istri menggugat cerai suami, diketahui bahwa hampir tidak ada perbedaan antara hukum Islam dan hukum Undang-uang yang dibuat oleh pemeritah Indonesia. Hanya saja perbedaan dalam pelaksanaan yang disesuaikan denga keadaan Indonesia sebagai negara demokrasi yang menganut paham undangundang.

Hukum Islam sendiri ternyata $k h u l u^{\prime}$ atau seorang istri menggugat cerai terhadap suami telah terjadi sejak jaman Rasulullah saw. hidup bahkan dengan penjelasan dan alasan yang diberikan oleh sang istri, dengan mudah Rasulullah mengabulkan permohonannya untuk menggugat sang suami; yang artinya khulu' dalam pandangan hukum Islam mubah (boleh-boleh saja) dengan mengikuti beberapa ketentuan dan syarat yang benar dan dapat dibenarkan oleh syariat dan hukum Islam serta tidak dibuat-buat.

Demikian halnya dalam putusan yang ditetapkan oleh Undang-undang pernikahan dan perceraian yang di atur dalam Kompilasi Hukum Islam (KHI), tampaknya mengambil keputusan yang sama dengan hukum Islam yang membolehkan seorang istri menggugat seorang suami untuk bercerai selama memenuhi syarat dan ketentuan yang berlaku.

Sangaji Jurnal Pemikiran Syariah dan Hukum 


\section{DAFTAR PUSTAKA}

Al Syarifain Khadīm al Haramain. T.th. Al-Qur'an dan Terjemahan Maknanya. Komplek Percetakan Al Qur'an Al Karim Raja Fahd.

Ali Zainuddin. 2009. Hukum Perdata Islam di Indonesia. Jakarta: Sinar Grafika.

Hoerudin Ahrum. 1999. Pengadilan Agama (Bahasan Tentang Pengertian, Pengajuan Perkara, dan Kewenangan Pengadilan Agama Setelah Berlakunya Undang-Undang Nomor 7 Tahun 1989 Tentang Peradilan Agama). Bandung: PT. Aditya Bakti. Imanullah Rijal. 2016. Poligami dalam Hukum Islam Indonesia (Analisis Terhadap Putusan Pengadilan Agama NO. 915/ Pdt.G/ 2014/PA.BPP Tentang Izin Poligami). Mazahib; Jurnal Pemikiran Hukum Islam. Vol. XV, No. 1 Juni 2006. Hal. 108. Lihat juga: Sudarsono. 2009. Kamus Hukum, Cet. VI. Jakarta: Rineka Cipta.

Rahmat Hakim. Tth. Hukum Perkawinan Islam. Bandung: Pustaka Setia.

Ghazaly Abd. Rahman. 2006. Fiqh Munakahat, Cet. II. Jakarta: Kencana.

Ardhian Reza Fitra dkk. 2015. Poligami dalam Hukum Islam dan Hukum Positif Indonesia Serta Urgensi Pemberian Izin Poligam di Pengadilan Agama. Jurnal Privat Law, Vol. III, No. 2 Juli-Desember 2015.

Rohidin. 2016. Pengantar Hukum Islam, Dari Semenanjung Arabia hingga Indonesia, Cet, I. Yogyakarta; Lintang Rasi Aksara Books.

Ichsan Muchammad. 2015. Pengantar Hukum Islam, Cet. I. Yogyakarta; Gramasurya.

Undang-Undang Republik Indonesia Nomor 12 Tahun 2011 Tentang Pembentukan Peraturan Perundang-Undangan. 
Suhendra Darmiko. 2016. Khulu' dalam Persfektif Hukum Islam. Jurnal Asy-Syar'iyyah Vol. 1 No. 12016.

Abu Zahrah Muhammad. 2005. Ahwal Syahkshiyyah. Kairo: Daar el Fikri.

Hamka. 2015. Tafsir Al-Azhar, Juz I. Jakarta; Gema Insani.

Abidin Slamet. 1999. Fiqih Munakahat, Cet. II. Bandung: CV. Pustaka Setia.

Al Jurzawi Ali Ahmad. 1992. Hikmah Al-Tasyri Wa Falsafatuh (Falsafah dan Hikmah Hukum Islam), Alih bahasa Hadi Mulyo dan Sabahus Surur. Semarang: CV As-Syifa.

Undang-undang Republik Indonesia Nomor 1 Tahun 1974 Tentang Perkawinan.

Peraturan Pemerintah Republik Indonesia Nomor 9 Tahun 1975 Tentang Pelaksanaan Undang-Undang Nomor 1 Tahun 1974

Sudono. 2019. Penyelesaian Perceraian dengan Khulu dan Akibat Hukumnya. diakses pada 15 Maret 2019. https://www.pablitar.go.id/informasi-pengadilan/164-penyelesaianperceraian-dengan-khulu-dan-akibat-hukumnya.html.

Sudono. 2014. Senarai Pembaharuan Hukum Peradilan Agama Kajian Hukum Formil dan Materiil; Edisi Revisi. Surabaya PTA.

Sangaji Jurnal Pemikiran Syariah dan Hukum 